\title{
Electing Women to the Dáil: Gender Cues and the Irish Voter.
}

NOTE: This is a preprint of an article submitted for consideration in Irish Political Studies (C)

[Published 2011 Volume 26:4] [copyright Taylor \& Francis];

Irish Political Studies is available online at:

http://www.tandfonline.com/doi/abs/10.1080/07907184.2011.619746

\section{Gail McElroy and Michael Marsh}

Trinity College, Dublin

\begin{abstract}
:
At no time in history has the number of women elected to Dáil Eireann surpassed fourteen percent of the total membership. In spite of significant social changes, the use of a proportional electoral system and no obvious bias among voters, the number of female Teachtaí Dála (TDs) remains stubbornly low by international standards. This paper examines why, if the prospect for women's election are relatively good, so few women end up in public office. Using both aggregate and survey data, we explore the issues of incumbency advantage, the electorate's attitudes and the candidates differing experiences of the political process. The evidence suggests that, all else equal, female candidates have as good a chance of getting elected as their male counterparts and the real difficulties in achieving equitable representation lie elsewhere, in the candidate emergence and nomination stages of the election game.
\end{abstract}

\section{Introduction:}

In the 2007 Irish general election, a mere 22 of the 165 members elected to Dáil Eireann were women, exactly the same number as had been elected in 2002. Despite significant social changes and an exponential growth in women's labour force participation, the percentage of women elected as TDs has remained static over the course of the past two decades. Furthermore, there has been no breakthrough in representation at the local level either, with women achieving a mere 16 percent of seats in the city and county council elections of 2009. Within the European Union, only Hungary, Romania, Cyprus and Malta have lower proportions of women in their national parliaments. In what follows we explore a series of factors that might help us explain the puzzle of why Ireland elects so few women.

The literature on gender and politics explains cross-national variation in election rates largely in terms of contextual and structural factors. One of the most consistent findings to emerge from this voluminous body of work is the very positive impact of proportional electoral systems (PR) on women's representation, with PR almost universally acknowledged to increase the number of women in elected office (Kenworthy \& Malami 1999; McAllister \& Studlar 2002; Salmond 2006). While closed list PR systems are generally acknowledged to best facilitate large numbers of women in Parliament (Lakeman 1994), the multi-member nature of PR-STV constituencies should provide selectorates with more opportunities to nominate women than single member district (SMD) systems (Matland and Brown 1992; Rule 1987). Nonetheless, it is striking that Ireland has been overtaken in 
the past decade by the United Kingdom and France, two single member district electoral systems, in the international rankings of women in parliament. The recent surge in the numbers of women in public office in the UK and France has not been mirrored in Ireland.

A second key finding in cross-national studies is the strong relationship between women's rates of labour force participation and levels of representation, particularly in the industrialized world (McDonagh 2002, Matland 1998). But the dramatic changes in rates of employment of women in Ireland in the past three decades, from historically very low levels to above the EU average, do not appear to have had knock-on effects in parliament. Cultural differences are also frequently invoked to explain the cross national trends in representation levels, in particular religious heritage (Inglehart 1979; Rule 1987) but more recent research suggests that the main differences are between dominant Christian countries (whether Protestant or Roman Catholic) and others (Reynolds 1999) or between post-industrialist and more traditional societies (Inglehart and Norris 2003) and as such this explanation does not adequately explain Ireland's poor showing in electing legislative women. In what follows, we attempt to answer why Ireland performs worse than one might expect, given the contextual and structural factors, through an examination of both aggregate and survey evidence from the most recent election in 2007. We first explore the performance of women candidates in terms of their overall electoral performance. We then examine the evidence in the Irish National Election survey (INES) to see if we can identify a profile of a voter most likely to vote for female (of male) candidates. Finally, we examine the evidence from the 2007 candidate survey to explore whether male and female candidates experience the nomination and electoral process in a similar fashion.

\section{Female Candidates and the Vote}

Of the 470 candidates who contested the 2007 national election in the Republic of Ireland a mere $82(17 \%)$ were women. But, as Table 1 clearly illustrates, the proportion of female candidates did vary quite significantly across the political parties. Both of the main parties, Fianna Fáil and Fine Gael, ran significantly more male candidates than the four smaller parties. A full quarter of the Green Party's candidates were women and the Labour Party, the Progressive Democrats and Sinn Féin also fielded relatively high numbers. The low number of candidates for the two larger parties may simply reflect the realties of the incumbency advantage that operates in Ireland rather than a systematic bias against women (Gallagher 2007) and we explore this possibility below. Where incumbency is one of the best predictors of re-election, the fact that most incumbents are male, serves as an obstacle to the election of women (Schwindt Bayer 2005).

\section{TABLE 1 ABOUT HERE}

We begin our analysis by exploring if women candidates performed systematically worse than male candidates in terms of their first preference vote totals. While PR-STV does involve the transfer of votes, the safest route to election is to ensure as large a first preference count as possible. If female 
candidates are obtaining fewer first preferences than male candidates they will be at a disadvantage in the election stakes. The dependent variable in this analysis is VOTE, which is a count of the number of first preference votes a candidate obtained, relative to his or her fellow competitors. Specifically, the dependent variable measures a candidate's deviation from the mean candidate first preference vote in his/her constituency. This approach is intended to capture how well a candidate does, in terms of his or her total number of first preferences, relative to other candidates in the election, whilst controlling for the different number of votes cast in each constituency. ${ }^{1}$

The key independent variable of interest in the model is the GENDER of the candidate (a dichotomous variable coded 0 for men and 1 for women). We expect this variable to have a negative sign if female candidates obtain fewer first preference votes. In addition, several other candidate characteristics are controlled for through the variables: SPENDING, INCUMBENT and MINISTER. The INCUMBENT variable measures whether or not the candidate was a sitting member of the Dáil (0 if no, 1 if yes). The incumbency rate in Ireland is high by international standards, with typically around three-quarters of sitting TDs getting re-elected (Schwindt-Bailer 2005) and this may serve as an additional impediment to women's election prospects. MINISTER captures whether or not the candidate was a sitting minister ( 0 if no, 1 if yes), it is theorized that such candidates are additionally advantaged in their vote getting abilities and women tend to have low representation at the cabinet table. SPENDING is the standardized Euro expenditure of the candidate over the course of the campaign period. Money is increasingly important in Irish campaigns (Benoit and Marsh 2010) and if women tend to have smaller war chests than their male counterparts, they will again be disadvantaged. Also included in the full model are the interactions of all of these variables with the key variable of interest $G E N D E R$, to capture whether the impact of incumbency, ministerial office and spending varies as a function of the candidates Gender. Finally, dummies are also created for the party affiliation of the candidate.

The results of the regression analysis are presented in Table 2. Four separate models are estimated, two simple models with just the key independent variable for all candidates and for the subsection of candidates who are non-incumbents. And second, two fuller models with all of the control variables for both the full set and sub-set of candidates. In none of these models does the gender of the candidate prove significant in predicting the number of first preferences received, even in the most parismonious model. Indeed, in three of the four models the sign on the GENDER variable is positive (though not significant), contrary to expectations. In the full model in column 2, SPENDING, INCUMBENT and MINISTER are included, along with the party dummies and interaction terms. All three variables, not surprisingly, achieve significance and in the expected direction. Candidates who spend more money, have served already as a TD, and better still as a minister get more votes than their more impoverished non-incumbent challengers. Being a female minister has, however, a negative impact on the number of first preferences achieved (significance of the interaction term GENDER $\mathrm{x}$ MINISTER). Though given there were only three candidates in this position, we should not read too

\footnotetext{
${ }^{1}$ Further details on the measure can be obtained from McElroy and Marsh 2010.
} 
much into the results. The two models were rerun on the subset of non-incumbent candidates (models 3-4) in order to check if the impact of gender is moderated by incumbency but no differences emerged. There is nothing particularly advantageous or disadvantageous about being a woman per se. When controlling for all of the standard variables, we find there is no evidence from the aggregate analysis that female candidates are discriminated against in terms of their gender. From these aggregate results it would seem that one of the major encumbrance to gender parity is the advantage incumbents have in elections. Nonetheless, of the In the next section, we explore in some more detail whether or not the impact of candidate gender is conditional on voter characteristics. While the aggregate evidence suggests that women candidates are not systematically underperforming in their vote returns, we would like to also know if there is a particular profile of voter that systematically votes for women (or men) in the ballot box.

\section{Voter Survey Analysis}

The Irish National Election Study survey data matched with the candidate data permits us to consider voter characteristics as well as candidate characteristics as well as the interactions between the two to identify if there are a set of voters who are systematically more likely to vote for women (or men). We make use of 3 separate dependent variables in the analysis that follows. The first, PREFERENCE, captures whether or not the respondent expressed any preference for a female candidate and if so which preference; the second, THERM, measures the thermometer rating score given to candidate $i$ by the respondent $j$ and the third, PREFERENCE1-3, captures whether or not the respondent gave a high preference $(1,2$ or 3$)$ to the candidate in question. The independent variables in the analysis include the demographic and attitudinal characteristics of voters that might be expected, in the light of previous research (McElroy and Marsh 2010), to identify those more likely to support women candidates: WOMAN, AGE, CLASS, IDEOLOGY, FEMINIST, KNOWLEDGE, PARTY CANDIDATE, WEAKNESS OF PARTY ID, PARTY ATTACHMENT and PARTY CENTRED VOTER. The key variable of interest is WOMAN, which is intended to capture the propensity of women to vote for women, (measured as a standard dichotomous variable: 0 if respondent is male and 1 if female). $A G E$ is measured in years. The expectation in the literature is that younger people will be more likely to vote for women. CLASS is a dichotomous variable that distinguishes manual from non-manual workers, with the latter theorized to be more inclined to vote for women. IDEOLOGY is measured using an 11-point left right self-placement scale with 0 representing the far left and 10 the far right. The expectation is that more left wing respondents will favour women. Political KNOWLEDGE is intended to capture political engagement and uses the political knowledge scale from the INES. This comprised five factual closed ended questions with four options provided with each. PARTY CANDIDATE is a simple dichotomous variable that captures whether the candidate under consideration is from a party with which the respondent self identifies himself with: i.e. reports himself as feeling close to. We also include a variable that measures the strength of the respondent's party identification, we reason that where this is strong, the voter will be driven to vote the party line regardless of the gender of the candidate. This 
variable is measured as a dichotomy where 1 is feeling close to a particular party and 0 is not. Finally, PARTY CENTRED VOTER captures how important candidate centred voting is for the respondent. This measure is a three point scale composite of two variables in the INES and ranges from -1 (candidate centred) to 1 (party centred). A specific attitudinal question on gender and politics was included for the first time in the 2007 INES, this asked respondents on a seven point scale whether they agreed or disagreed with the statement "In general things would improve if there were more women in politics". We label this variable, FEMINIST, which is a simple dichotomous measure distinguishing between those who agree and those who disagree with (or are neutral about) the statement. We expect that women more politizised attitudes to gender issues in politics to be more inclined to vote for women candidates. Finally, for the Preference model we control for the number for preferences cast as some respondents express only one preference and others complete the full ballot. For the THERM models we also control for a respondent's mean rating of other candidates as respondents may treat these scales differently and we are interested in the relative ratings of women and men by the respondent in question.

Table 3 presents the results of this analysis for six separate models using both a parsimonious and full model for each of the three dependent variables. It is important to stress that the analysis was confined to female candidates, however the results are exactly equivalent to a model in which both male and female candidates were included. ${ }^{2}$ The first column in Table 3 reports the results of the parsimonious linear regression model with PREFERENCE as the dependent variable and WOMAN and PARTY CANDIDATE as independent variables. As is clearly evident from the results in column 1 the only substantive variable that is significant is whether or not the candidate under consideration is from a party the respondent identifies with. In model 5 , where a high preference for the candidate is the dependent variable, PARTY CANDIDATE is yet again the only variable to reach significance. Similar results are found with the THERMOMETER scores, though here it seems women respondents are more likely to rate women candidates more highly but interestingly this does not translate into giving them higher preferences. These three models taken together find little evidence in favour of the hypothesis that women respondents are more likely to vote for female candidates than.

The results from the fuller model (models 2,4 and 6) also fail to find any evidence in favour of the hypothesis that women favour female candidates; nowhere does WOMAN reach significance. Nor do we find any evidence that any particular sub-group of women respondents is more inclined to vote for women candidates (insignificant interaction terms). The only exception to this is that women with low levels of party identification are less likely to assess women candidates favorably on the thermometer scales but the effect is small: only 4 points on the thermometer scale (range 0-100) across the full range of the variable. Moreover, that evaluation does not appear to translate into actual electoral support (preferences cast) - a result that perhaps underlines the difference between thermometer scores and voting behavior. The variable FEMINIST is however significant in models 4

\footnotetext{
${ }^{2}$ By including male as well as female candidates however, we would have to include third order interaction terms which only serve to obfuscate the central findings, not to mention making an already large table of output considerably larger.
} 
and 6, suggesting that respondents (male and female) who favour the entry of more women into politics are more likely to rate women candidates highly and also to give them a higher preference.

TABLE 2 ABOUT HERE

\section{Evidence from the 2007 Candidate Survey}

While the incumbency advantage is an impediment to raising the overall number of women in the Dáil, this factor cannot explain why there are systematic differences in the numbers of male and female challengers at election time. In 2007, of the 324 non-incumbent candidates who contested the election, fully $262(81 \%)$ were men. International research suggests that women are less likely than men to be recruited into politics (Burns, Schlozman and Verba 2001), they are less likely to receive encouragement and support to run for office from party and elected officials and even among the highly educated professionals they are less likely to think they are qualified to run (Lawless and Fox 2005). To explore the possibility that there is a gender gap in political ambition or that parties fail to recruit and encourage women to run for office, we turn to the 2007 Candidate Survey, which asked the candidates themselves about their experience of the electoral process.

The survey was conducted in the immediate aftermath of the election and was sent to every competitor. The response rate was just under 40 percent, which is not out of line with international experience. The incumbent-non-incumbent response rate exactly mirrored the split in the overall universe of candidates and the gender split in responses was similarly reflective of the overall population. However, the response rate from Labour Party candidates was somewhat higher than average, while they constituted 11 percent of candidates they comprise 17 percent of respondents. Furthermore, we also have a sample selection problem in that we do not survey the pool of 'potential' candidates but rather those who chose to run, we are thus censoring our data. Removed from the sample are the all of 'potential' legislative candidate, those who were discouraged (or at least not encouraged) to run. This may lead to an underestimation of gender differences.

For the first time in an Irish Candidate Survey, the candidates were presented with a battery of statements that explicitly tapped their beliefs about the under-representation of women. These statements attempt to capture open manifestations of gender bias but also differences in the opportunity structure of men and women. Respondents were asked to either (strongly) agree or disagree with a statement such as 'Not enough women come forward to be considered as candidates'. In Table 3 we present the results from a comparison of the responses of male and female candidates to these statements. The first striking element to be taken from this analysis is that there does not appear to be a traditional view among candidates of politics as being male only preserve. Very few male or female respondents believed that women were not qualified for political careers, that they didn't fit into parliamentary life or that they were not interested in politics. Interestingly, more women than men agreed with the statement that "Women Don't Have Right Experience and Education", though the number is small and the difference is not statistically significant.

The second striking result is that female candidates strongly believe that parties do not give 
women adequate opportunities. 73 percent of female candidates in the survey felt that this was the case, compared with only 29 percent of male candidates. The strongly significant difference hints at the very different experiences of male and female candidates in getting nominated. Both male and female candidates tended to subscribe to the supply side model explanation for the under representation of women, though male candidates were more likely ( 91 percent versus $74 \%$ ) to agree with the statement, that "not enough women come forward to be considered". Another interesting finding, which hints at the political ambition and socialization theses for under representation of women is the finding that far more women candidates ascribe to the view that "women don't have the confidence to stand". One in two female respondents agreed with this statement compared with less than one in five men. Women candidates seem to believe that at the critical candidate emergence phase of the electoral process gender plays a role. Both male and female candidates believe that family responsibilities inhibit women's political careers, echoing research findings that the traditional division of labour in households may lead women to consider their family obligations more carefully than their male counterparts (Conway, Steuernagel and Ahern 1997). Interestingly, and despite much research to the contrary, 17 percent of male respondents and almost one in three women respondents believe that voters prefer male to female candidates.

\section{Conclusion:}

Does the continued under-representation of women in Ireland matter? Women's representation may carry symbolic value for democracy but does it affect policy outcomes? The literature on this relationship between the descriptive and substantive representation of women (Pitkin 1967) is large and here we simply examine briefly one aspect of the by asking do women have different policy priorities than men? The candidate survey asked respondents what they believed to be the most important issue facing the country and while the top themes respondents, in particular w 


\section{References:}

Benoit, K and M. Marsh. 2010. Incumbent and Challenger Campaign Spending Effects in Proportional Electoral Systems: The Irish Elections of 2002. Political Research Quarterly, 63, 1:159-173.

Burns, Nancy, Kay Scholzman, and SidneyVerba. 2001. The Private Roots of Public Action: Gender, Equality, and Political Participation. Cambridge: Harvard University Press.

Conway, Margaret, Gertrude Steuernagel and David Ahern 1997. Women and Political Participation. Washington: Congressional Press.

Fox, Richard and Jennifer Lawless. 2010. 'Entering the Arena? Gender and the Decision to Run for Office' in Mona Lena Krook and Sarah Childs (eds.), Women, Gender and Politics: A Reader. Oxford: Oxford University Press.

Gallagher, Michael. 2007. 'The Earthquake that Never Happened: Analysis of the Results' in Michael Gallagher and Michael Marsh (eds), How Ireland Voted. Basingstoke: Palgrave McMillan.

Inglehart, Margaret. 1979. 'Political Interest in West European Women.' West European Politics.

Inglehart, R. and P. Norris. 2003a. Rising Tide: Gender Equality and Cultural Change Around the World. New York: Cambridge University Press

Kenworthy, Lane and Melissa Malami. 1999. 'Gender Inequality in Political Representation: A Worldwide Comparative Analysis.' Social Forces 78(1): 235-269.

Lakeman, Enid. 1994. 'Comparing Political Opportunities in Great Britain and Ireland' in W. Rule and J. Zimmerman (eds) Electoral Systems in Comparative Perspective. Westport Connecticut: Greenwood Press.

Lawless, Jennifer and Richard Fox. 2005. It Takes A Candidate: Why Women Don't Run for Political Office. New York: Cambridge University Press.

McAllister, I. \& Studlar, D. (2002). Electoral systems and women's representation: A long-term perspective. Representation 39(1): 3-14.

McElroy, Gail and Michael Marsh. 2010. Candidate Gender and Voter Choice: Analysis from a Multimember Preferential Voting System. Political Research Quarterly. 63(4) 822-833.

Matland, Richard, and Deborah Dwight Brown .1992. District magnitude's effect on female representation in US state legislatures. Legislative Studies Quarterly 17: 469-492.

Matland, R. 1998. Women's Representation in National Legislatures: Developed and Developing Countries." Legislative Studies Quarterly23, no. 1: 109-125

McDonagh, Eileen. 2002. "Political Citizenship and Democratization: The Gender Paradox". American Political Science Review 96 (3):535-552.

Paxton, P, M. Hughes and M. Painter. 2010. 'Growth in Women's Political Representation: A Longitudinal Exploration of Democracy, Electoral System and Gender Quotas' European Journal of Political Research 49 (1): 25-52.

Pitkin, Hanna. 1967. The Concept of Representation. Berkeley: University of California Press.

Rule, Wilma. 1987. Electoral Systems, Contextual Factors and Women's Opportunity for Election to Parliament in Twenty-Three Democracies. Western Political Quarterly 40:477-98.

Salmond, Rob. 2006. Proportional representation and female parliamentarians. Legislative Studies 
Quarterly 31(2): 175-204.

Schwindt-Bayer, Leslie A. (2005) “The Incumbency Disadvantage and Women's Election to Legislative Office." Electoral Studies 24: 227-44. 
Table 1: Number of Women Candidates by Party 2007

\begin{tabular}{lcc}
\hline \multicolumn{1}{c}{ Party } & $\begin{array}{c}\text { Percent } \\
\text { Female }\end{array}$ & $\begin{array}{c}\text { Total } \\
\text { Candidates }\end{array}$ \\
\hline Fianna Fáil & 13.20 & 106 \\
Fine Gael & 16.50 & 91 \\
Labour & 22.00 & 50 \\
Green Party & 25.00 & 44 \\
Sinn Féin & 24.40 & 41 \\
Progressive Democrats & 23.30 & 30 \\
Others & 12.90 & 31 \\
Independents & 12.98 & 77 \\
Total & 17.45 & 470 \\
\hline
\end{tabular}


Table 2: Performance of Candidates

\begin{tabular}{|c|c|c|c|c|}
\hline & \multicolumn{2}{|c|}{ All Candidates } & \multicolumn{2}{|c|}{ Non-Incumbents } \\
\hline & (1) & (2) & (3) & (4) \\
\hline & Vote & Vote & Vote & Vote \\
\hline \multirow[t]{2}{*}{ Gender } & -.0804 & 0.0751 & .1014 & 0.0875 \\
\hline & $(-0.82)$ & $(0.49)$ & $(1.17)$ & $(0.64)$ \\
\hline \multirow[t]{2}{*}{ Minister } & & $1.269^{* * *}$ & & \\
\hline & & $(9.92)$ & & \\
\hline \multirow[t]{2}{*}{ Spending } & & $0.0000252^{* * *}$ & & $0.0000267^{* * *}$ \\
\hline & & $(9.21)$ & & (9.53) \\
\hline \multirow[t]{2}{*}{ Incumbent } & & $0.514^{* * *}$ & & \\
\hline & & $(9.67)$ & & \\
\hline \multirow[t]{2}{*}{ Gender x Minister } & & $-0.939^{* *}$ & & \\
\hline & & $(-3.12)$ & & \\
\hline \multirow[t]{2}{*}{ Gender x Spending } & & -0.00000526 & & -0.00000284 \\
\hline & & $(-0.81)$ & & $(-0.45)$ \\
\hline \multirow[t]{2}{*}{ Gender $\mathrm{x}$ Incumbent } & & 0.0837 & & \\
\hline & & $(0.60)$ & & \\
\hline \multirow[t]{2}{*}{ Fianna Fáil } & & $0.762^{* * *}$ & & $0.912^{* * *}$ \\
\hline & & $(9.83)$ & & $(10.00)$ \\
\hline \multirow[t]{2}{*}{ Fine Gael } & & $0.644^{* * *}$ & & $0.622^{* * *}$ \\
\hline & & $(8.88)$ & & $(8.42)$ \\
\hline \multirow[t]{2}{*}{ Labour } & & $0.191^{*}$ & & 0.0486 \\
\hline & & $(2.20)$ & & $(0.57)$ \\
\hline \multirow[t]{2}{*}{ Greens } & & 0.0985 & & 0.0976 \\
\hline & & $(1.17)$ & & $(1.22)$ \\
\hline \multirow[t]{2}{*}{ Progressive Democrats } & & $-0.308^{* *}$ & & $-0.251^{* *}$ \\
\hline & & $(-2.93)$ & & $(-2.61)$ \\
\hline \multirow[t]{2}{*}{ Sinn Féin } & & $0.338^{* * *}$ & & $0.294^{* * *}$ \\
\hline & & $(3.79)$ & & $(3.55)$ \\
\hline \multirow[t]{2}{*}{ Gender x FF } & & -0.0527 & & -0.365 \\
\hline & & $(-0.29)$ & & $(-1.90)$ \\
\hline \multirow[t]{2}{*}{ Gender X FG } & & -0.00318 & & -0.0701 \\
\hline & & $(-0.02)$ & & $(-0.42)$ \\
\hline \multirow[t]{2}{*}{ Gender x Labour } & & 0.162 & & 0.147 \\
\hline & & $(0.82)$ & & $(0.65)$ \\
\hline \multirow[t]{2}{*}{ Gender x Greens } & & 0.0678 & & 0.0377 \\
\hline & & $(0.35)$ & & $(0.22)$ \\
\hline \multirow[t]{2}{*}{ Gender x PDs } & & -0.0760 & & -0.0241 \\
\hline & & $(-0.33)$ & & $(-0.10)$ \\
\hline \multirow[t]{2}{*}{ Gender x SF } & & -0.124 & & -0.123 \\
\hline & & $(-0.63)$ & & $(-0.70)$ \\
\hline \multirow[t]{2}{*}{ Constant } & .0140 & $-0.952^{* * *}$ & $-0.354^{* * *}$ & $-0.965^{* * *}$ \\
\hline & $(0.34)$ & $(-20.37)$ & $(-9.39)$ & $(-23.65)$ \\
\hline R-squared & .00 & .75 & .00 & .69 \\
\hline $\mathrm{N}$ & 470 & 470 & 324 & 324 \\
\hline
\end{tabular}

$t$ statistics in parentheses 


\begin{tabular}{|c|c|c|c|c|c|c|}
\hline & $\begin{array}{l}\text { (1) } \\
\text { Preference }\end{array}$ & $\begin{array}{l}\text { (2) } \\
\text { Preference }\end{array}$ & $\begin{array}{l}\text { (3) } \\
\text { Therm }\end{array}$ & $\begin{array}{c}\text { (4) } \\
\text { Therm }\end{array}$ & $\begin{array}{c}\text { (5) } \\
\text { Preferences } \\
1-3\end{array}$ & $\begin{array}{c}\text { (6) } \\
\text { Preferences } \\
1-3\end{array}$ \\
\hline \multirow[t]{2}{*}{ Woman Respondent } & 0.0836 & -0.250 & $0.418 * *$ & 0.726 & 0.181 & 0.508 \\
\hline & $(0.87)$ & $(-0.71)$ & $(2.41)$ & $(1.09)$ & $(1.57)$ & $(0.93)$ \\
\hline \multirow[t]{2}{*}{ Own Party Candidate } & $-0.484 * * *$ & $-0.921 * * *$ & $2.849 * * *$ & $3.468 * * *$ & $2.523 * * *$ & $3.151 * * *$ \\
\hline & $(-2.67)$ & $(-4.29)$ & $(7.54)$ & $(7.90)$ & $(7.85)$ & $(8.68)$ \\
\hline \multirow{2}{*}{$\begin{array}{l}\text { Woman x Own Party } \\
\text { Candidate }\end{array}$} & 0.0578 & -0.136 & -0.0385 & 0.618 & -0.406 & -0.0934 \\
\hline & $(0.26)$ & $(-0.46)$ & $(-0.072)$ & $(0.99)$ & $(-0.88)$ & $(-0.18)$ \\
\hline \multirow[t]{2}{*}{ Weakness of Party ID } & & $0.541 * * *$ & & $-0.867 * * *$ & & $-0.756 * * *$ \\
\hline & & $(3.22)$ & & $(-3.16)$ & & $(-3.46)$ \\
\hline \multirow{2}{*}{ Class } & & 0.00397 & & 0.129 & & 0.0191 \\
\hline & & $(0.030)$ & & $(0.58)$ & & $(0.11)$ \\
\hline \multirow[t]{2}{*}{ Knowledge } & & -0.0942 & & 0.0598 & & 0.127 \\
\hline & & $(-1.50)$ & & $(0.53)$ & & $(1.47)$ \\
\hline \multirow[t]{2}{*}{ Age } & & -0.000938 & & 0.00259 & & 0.00171 \\
\hline & & $(-0.25)$ & & $(0.36)$ & & $(0.31)$ \\
\hline \multirow[t]{2}{*}{ Feminist } & & -0.171 & & $0.687 * * *$ & & $0.570 * * *$ \\
\hline & & $(-1.36)$ & & $(3.06)$ & & $(3.27)$ \\
\hline \multirow{2}{*}{ Party-Centred Voter (PCV) } & & $0.160 *$ & & -0.00883 & & -0.0530 \\
\hline & & $(1.87)$ & & $(-0.057)$ & & $(-0.47)$ \\
\hline \multirow[t]{2}{*}{ Woman * Weak Partyid } & & 0.202 & & $-0.827 * *$ & & -0.418 \\
\hline & & $(0.79)$ & & $(-2.09)$ & & $(-1.30)$ \\
\hline \multirow[t]{2}{*}{ Woman * Class } & & -0.141 & & 0.0603 & & 0.0722 \\
\hline & & $(-0.81)$ & & $(0.19)$ & & $(0.29)$ \\
\hline \multirow[t]{2}{*}{ Woman x Knowledge } & & 0.0110 & & 0.0146 & & -0.167 \\
\hline & & $(0.14)$ & & $(0.094)$ & & $(-1.49)$ \\
\hline \multirow[t]{2}{*}{ Woman * Age } & & 0.00261 & & -0.00710 & & 0.00254 \\
\hline & & $(0.49)$ & & $(-0.69)$ & & $(0.32)$ \\
\hline \multirow[t]{2}{*}{ Woman * Feminist } & & 0.252 & & 0.0227 & & -0.156 \\
\hline & & $(1.37)$ & & $(0.066)$ & & $(-0.63)$ \\
\hline \multirow[t]{2}{*}{ Woman * PCV } & & -0.0831 & & -0.148 & & 0.0247 \\
\hline & & $(-0.72)$ & & $(-0.70)$ & & $(0.16)$ \\
\hline \multirow[t]{2}{*}{ Number of Preferences } & $0.587 * * *$ & $0.578 * * *$ & & & & \\
\hline & $(26.7)$ & $(27.6)$ & & & & \\
\hline \multirow{2}{*}{$\begin{array}{l}\text { Mean rating of male } \\
\text { candidates }\end{array}$} & & & $0.331 * * *$ & $0.381 * * *$ & & \\
\hline & & & $(5.67)$ & $(6.63)$ & & \\
\hline \multirow[t]{2}{*}{ Constant } & $0.898 * * *$ & $1.224 * * *$ & $1.843 * * *$ & 0.940 & $-1.523 * * *$ & $-2.098 * * *$ \\
\hline & $(8.73)$ & $(4.07)$ & $(3.74)$ & $(1.53)$ & $(-18.3)$ & $(-5.68)$ \\
\hline Observations & 756 & 756 & 1370 & 1370 & 2090 & 2090 \\
\hline R-squared & 0.57 & 0.59 & 0.09 & 0.13 & & \\
\hline
\end{tabular}

Robust $\mathrm{t}$ statistics in parentheses. Robust $\mathrm{z}$ statistics for models 5 and 6.

$* * * \mathrm{p}<0.01, * * \mathrm{p}<0.05, * \mathrm{p}<0.1$ 


\begin{tabular}{lccc}
\hline & $\begin{array}{c}\text { Male } \\
\text { Candidates } \\
\text { Agreeing } \\
(\%)\end{array}$ & $\begin{array}{c}\text { Female } \\
\text { Candidates } \\
\text { Agreeing } \\
(\%)\end{array}$ & $\begin{array}{c}\text { Difference } \\
\%\end{array}$ \\
\hline Women are Not Given the Opportunity by Parties & 29 & 73 & $44^{* * *}$ \\
Women Don't Have the Confidence to Stand & 17 & 50 & $33^{* * *}$ \\
Not Enough Women Come Forward to be considered & 91 & 74 & $16^{* *}$ \\
Most Voters Prefer Male Candidates & 17 & 31 & 14 \\
Women put Families Above a Career in Parliament & 82 & 93 & 11 \\
Women Don't Fit Into Parliament & 3 & 3 & 0 \\
Women Don't Have Right Experience and Education & 2 & 6 & 4 \\
Women are not Interested In Politics & 8 & 6 & 2 \\
\hline
\end{tabular}

Chi-square significance level: **.01, ***.001

\begin{tabular}{|l|l|l|}
\hline Most Important issue facing country & $\begin{array}{l}\text { Male Candidates } \\
(\mathbf{\%})\end{array}$ & $\begin{array}{l}\text { Female Candidates } \\
(\mathbf{\%})\end{array}$ \\
\hline Economy & 21 & 13 \\
\hline Health & 15 & 18 \\
\hline Political Reform & 8 & 5 \\
\hline Environment & 8 & 21 \\
\hline
\end{tabular}

